\title{
Environmental induction models for the investigation of activity: Changes in glutathione peroxidase, a crucial factor of the antioxidant defence
}

\author{
Márta Erdélyi ${ }^{1}$, M. Mézes ${ }^{1}$, Györgyi Virág² \\ 1 "Szent István" University, Department of Nutrition, Gödöllö, Hungary \\ ${ }^{2}$ Institute for Small Animal Breeding and Nutrition, Gödöllö, Hungary \\ Received: March 26, 2001 \\ Accepted: July 5, 2001
}

Glutathione peroxidase enzyme superfamily plays significant role in the elimination of reactive oxygen free radicals in the animals. Many characteristics of these proteins have been revealed already, but their regulation is still not known. Several data suggest that some environmental factors have certain regulatory effect, while others propose strict genetic regulation.

In this report we present four different environmental induction models in which New Zealand white rabbits were used as experimental animals. In three models, free radical load of different origin, lipidperoxide load, application of a glutathione depletor or a prooxidant agent, was introduced. Beside these negative models a positive model was also constructed in which additive selenium was supplied.

Glutathione peroxidase activity was measured in blood serum, erythrocyte haemolysate and liver. Reduced glutathione, and malondialdehyde concentration in the liver were also determined.

According to the results, the established models are capable for analysing the enzyme activity $\times$ environmental interactions.

Keywords: glutathione peroxidase, peroxide load, selenium, prooxidant effect, glutathione depletion oxygen free radicals, environmental induction models, malondialdehyde

Correspondence should be addressed to

Márta Erdélyi

"Szent István” University

Department of Nutrition

H-2103 Gödöllő, Páter K. u. 1, Hungary

Phone: 36-28-410735

Fax: 36-28-410804

E-mail: erdelyi@fau.gau.hu 
There are many oxygen free radicals of various origin in the environment. Physiological processes in animals and human also produce such reactive particles. As free radicals have severe effect in living organisms, an effective defence system has developed, which consists of several enzymes and other scavenger molecules. Glutathione peroxidase is part of this system and it eliminates radicals through classical oxido-reduction reaction, with the use of reduced glutathione, as co-substrate.

Nowadays, it is known that the term glutathione peroxidase (GSHPx) refers to many different molecules. Basically, this enzyme family might be divided into two groups: selenium dependent GSHPX-s and glutathione-S-transferases. In the former group four isoenzymes are known - cytoplasmic (cGSHPx), extracellular (eGSHPx), phospholipid hydroperoxide (phGSHPx) and gastrointestinal (gGSHPx) forms. The common characteristic of these enzymes is the selenium content of their active site (2). In most tissues selenium dependent glutathione peroxidases has dominance over glutathione-S-transferases in free radical scavenging, as the kinetics of the former group is at least 10 fold faster than that of the latter one's.

It is well known that the activity of these enzymes is affected in some extent by the environment. Therefore, our research team has developed model systems for simulation of special environmental conditions to study these effects.

Due to the dominance of selenium dependent GSHPx among glutathione peroxidases and its selenium content, it is supposed that this microelement plays predominant role in the measurable glutathione peroxidase activity. It is verified already that selenium deficiency alters enzyme action, while the effect of additive selenium supply is a still matter of question. There are results suggesting that enzyme activity increases significantly with dietary selenium supplementation in chickens (1). Also close correlation was found in rabbit between selenium supply and GSHPx activity of blood plasma and RBC (18). However, correlation between enzyme activity and selenium supplementation is not first order type, as the enzyme activity seems to reach a maximum value (4).

As these enzymes act against different hydroperoxide radicals, high peroxide load should have severe effect on their activity. The most common source of peroxide load is lipid peroxide intake from rancid fat containing diet (10). According to preliminary studies of our research team, feeding peroxidised food results in changed GSHPx activity in different species (9).

There are several prooxidant agents in the environment inducing free radical production. Also a variety of pathological processes are known to have oxygen radical producing effect. Alloxan diabetes, which is known to increase free radical formation, is a well-documented method to create prooxidant environment (14). 
Another frequent method of experimentally induced oxidative stress is glutathione depletion. This method is based on the fact that reduced glutathione gives approximately 90 per cent of non-protein sulfhydryl groups in the cell (8). Loss of the sulfhydryl groups is a primary marker of oxidative damage (15). Several chemicals are used for inducing glutathione depletion, like diethylmaleate, butinion, sulfoximide and bromobenzene. This latter agent has general toxicity in hepatic and extrahepatic tissues, therefore it is appropriate for studying the general effects of GSH depletion (11).

To find environmental factors of glutathione peroxidase regulation, induction models were established with rabbit, as model animal. In this report, four of these models and their analyses are presented.

\section{Materials and Methods}

\section{Animals}

Halfsib New Zealand white rabbits at 10 weeks of age with similar body weight were divided into four groups (6 individuals in each group, 3 males and 3 females). Rabbits in the normal group (C) were fed for five weeks on basal diet, which was commercial broiler rabbit diet (dry matter (DM): $877 \mathrm{~g} / \mathrm{kg}$, crude protein: $180 \mathrm{~g} / \mathrm{kg} \mathrm{DM}$, crude fibre: $117.3 \mathrm{~g} / \mathrm{kg}$ DM, crude fat: $90.2 \mathrm{~g} / \mathrm{kg} \mathrm{DM}, \mathrm{N}$-free extract: $557 \mathrm{~g} / \mathrm{kg} \mathrm{DM}$ ).

In the other groups, different treatments were applied. In the selenium supplemented group rabbits were fed on basal diet supplemented with $0.3 \mathrm{ppm}$ organic selenium (SelenoYeast ${ }^{\circledR}$, Alltech, Lexington). For the peroxide load model, peroxidised sunflower oil was added to the basal diet in the amount of $2 \mathrm{~g} / \mathrm{kg}$ feed. For modelling the prooxidative environment, intravenous injection of alloxan monohydrate was applied 36 hours before extermination. In the fifth group, $13 \mathrm{mmol} / \mathrm{kg} \mathrm{b.w.} \mathrm{(body}$ weight) bromobenzene was applied per os 24 hours before extermination.

\section{Samples}

Extermination of the animals was done at 16 weeks of age. Blood was taken from the cervical vascular complex. Blood plasma and 1:9 erythrocyte haemolysate were stored at $-20{ }^{\circ} \mathrm{C}$ for further analyses. Liver samples (distal part of the right lobe) were obtained postmortem. $10,000 \mathrm{~g}$ supernatant fraction of the tissue homogenate (1:9 in physiological saline) was used for the activity and other measurements. 
Biochemical assays

Selenium concentration in feed, blood and liver was measured with flameless atomic absorption photometry (UNICAM 939 QZ AA spectrometer).

Glutathione peroxidase activity was measured with end-point direct assay (6). Enzyme activity was expressed as function of protein content of the samples. Protein concentration was determined with biuret method in blood plasma, and erythrocyte haemolysate (16), while Folin phenol reagent was used tissue samples (7).

MDA (malonyl dialdehyde) concentration was measured in the liver samples with TBARS (thiobarbituric acid reactive substances) method (12).

Reduced glutathione concentration in the liver was measured on the basis of Sedlak-Lindsay method (13).

\section{Statistics}

Measurement data were analysed with Excel 5.0 software utilizing two-way ANOVA analysis.

\section{Results}

Selenium supplementation: According to the measurements, selenium level in the normal and in the supplemented group was $0.126 \mathrm{ppm}$ and $0.314 \mathrm{ppm}$, respectively. Average selenium intake, based upon the feed consumption, was $13.96 \pm 0.5$ and $4.36 \pm$ $0.44 \mu \mathrm{g} / \mathrm{kg} \mathrm{BW} /$ day of the supplemented and the control animals. According to these data selenium intake of the supplemented group was only slightly lower, than the maximum safe dietary selenium of $15 \mu \mathrm{g} / \mathrm{kg} \mathrm{BW} /$ day (17).

Whole blood and liver selenium concentrations were measured in both groups. The walues were higher in each sample in the selenium-supplemented group (Table I), but the difference was significant only in the blood $(\mathrm{p}<0.01)$.

GSH (reduced glutathione) concentration: GSH concentration was measured in the liver. Significant $(\mathrm{P}<0.01)$ decrease was found in the depleted group as compared to the normal animals. Whereas, weaker, but still significant $(\mathrm{p}<0.05)$ decrease was found in the selenium supplemented group (Fig. 1). 
Table I

The effects of selenium supplementation

\begin{tabular}{lcc}
\hline \multicolumn{1}{c}{ Parameters } & Supplemented group & Normal group \\
\hline Daily feed intake $(\mathrm{g} /$ day $)$ & $143.15 \pm 15$ & $129 \pm 16$ \\
Daily Se intake $(\mu \mathrm{g} / \mathrm{kg} \mathrm{BW})$ & $13.96 \pm 0.5$ & $4.36 \pm 0.44$ \\
Se concentration in the blood $(\mu \mathrm{g} / \mathrm{l})$ & $99.7 \pm 8.3$ & $70.55 \pm 8.3$ \\
Se concentration in the liver $(\mu \mathrm{g} / \mathrm{kg} \mathrm{DM})$ & $983 \pm 164$ & $843.5 \pm 164$ \\
\hline
\end{tabular}

MDA concentration: The concentration of the malonyl dialdehyde in the liver was significantly higher in each group as compared to the normal one, except the selenium supplemented group (Fig. 1).

Enzyme activity: Glutathione peroxidase activity has shown similar changes in blood serum and liver samples. Every treatment has resulted in a drop in the activity, which was significant in each sample compared to the normal ones, except serum enzyme activity in prooxidant environment and in selenium supplementation. Measurements in the erythrocyte haemolysate samples were almost totally controversial. High activity increase was found in the group of peroxide load, selenium supplementation and prooxidant treatment, while activity has shown a slight decrease in the GSH depleted group as compared to the control (Fig. 2).

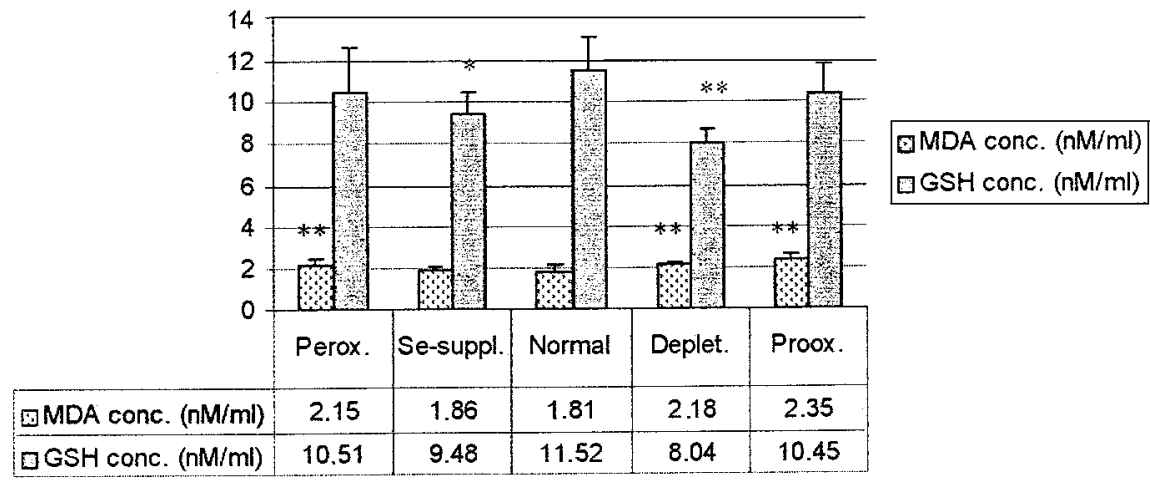

Fig. 1. GSH and MDA concentration in the liver 


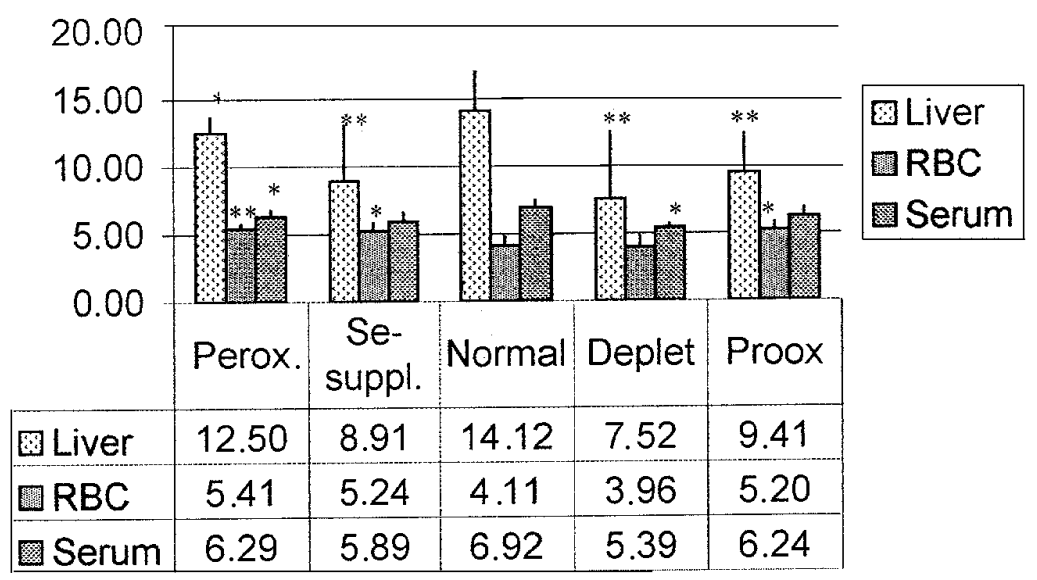

Fig. 2. Enzyme activity measured in blood serum, RBC haemolysate and liver samples in each treatment

\section{Discussion}

Selenium concentration: The significantly higher blood selenium level in the supplemented group means high intestinal absorption rate of the selenium enriched yeast, which is known to result in steady rise in the blood selenium concentration (3). The relatively small difference in the liver selenium concentration between the two groups might be in accordance with the finding of Humaloja and Mykkanen (5) as they showed that after dosing organic selenium, selenomethionine accumulation in the liver is relatively low.

Enzyme activity: In case of selenium supplementation the real reason of significant decrease in the enzyme activity in the liver and blood serum is not known. However, according to literature data it is thought that the selenium in excess might react with free reduced glutathione and forms selenodiglutathione (17) with it. This theory is well supported by the lower GSH concentration measured in the liver. As glutathione is the co-substrate of the GSHPx, the activity drop might be a consequence of the substrate deficiency.

Peroxide load resulted in high free radical production, which is verified by the increased MDA concentration in the liver. The contrary tendency in the enzyme activity might be explained with the saturation curve characterising the kinetics of the enzyme. This means that in free radical load the enzyme activity increases linearly in time until 
reaching a plateau value which is followed by a slow decrease in activity even at high free radical load (9). Therefore, the low activity values in the liver and blood serum would have been the signs of the final, so-called, exhausted phase of the enzyme. Red blood cells, however, have much more stable intracellular conditions, which results in a time shift of the saturation curve of the enzyme as compared to the former samples. Therefore, the enzyme activity is in the phase of linear increase in these samples at the time of measurements.

According to the glutathione measurements, bromobenzene treatment has resulted in a drastic glutathione depletion, and as it forms conjugate with the co-substrate of the enzyme, the drop found in the enzyme activity, was a definite consequence.

In the prooxidant treatment controversial findings were revealed. Alloxan treatment produced free radicals, which was verified by the high level of MDA measured in the liver. Significant rise in the enzyme activity in the red blood cells also agrees with the hypothesis of free radical induction in acute diabetes. However, low level of GSHPx activity in the liver is primarily the result of the increased level of protein concentration in these samples (data not shown). The reason of this latter finding is probably the destruction of intracellular structures resulting in protein release.

Altogether, the presented induction models are appropriately designed and verify crucial role of environmental factors in glutathione peroxidase action. However, some of the changes cannot be explained solely by environmental effects, which urge to focus our studies on genetic regulation of the enzyme as well.

\section{Acknowledgement}

This project has been supported by the National Scientific Research Fund (OTKA T-24145).

\section{REFERENCES}

1. Arai T, Sugawara M, Sako T, Motoyoshi S, Shimura T, Tsutsui N. Konno T: Glutathione peroxidase activity in tissues of chickens supplemented with dietary selenium. Comp. Biochem. Physiol. 107A, 245-248 (1994)

2. Avissar N, Slemmon JR, Palmer IS, Cohen HJ: Partial sequence of human plasma glutathione peroxidase and immunologic identification of milk glutathione peroxidase as the plasma enzyme. J. Nutr. 121, 1243-1249 (1991)

3. Clausen J, Nielsen SA: Comparison of whole blood selenium values and erythrocyte glutathione peroxidase activities of normal individuals on supplementation with selenate, selenite, L-methionine and high selenium yeast. Biol. Trace Elem. Res. 15, 125-138 (1988)

4. Gaál T (1998): Glutathione peroxidase activity and selenium status. In: Role of selenium in the environment and health, eds: Cser M, Sziklainé László I (In Hungarian) FRAG Bt. Budapest 
5. Humaloja T, Mykkanen HM: Intestinal absorption of ${ }^{75} \mathrm{Se}$-labeled sodium selenite and selenomethionine in chicks: effects of time, segment, selenium concentration and method of measurement. J. Nutr. 116, 142-148 (1986)

6. Lawrence RA, Burk RF: Glutathione peroxidase activity in selenium deficient rat liver. Biochem. Biophys. Res. Comm. 71, 952 (1976)

7. Lowry OH, Rosenbrough NJ, Farr AL, Randall RJ: Protein measurement with the Folin phenol reagent. J. Biol. Chem. 193, 265-275 (1951)

8. Meister A, Anderson ME: Glutathione. Annu. Rev. Biochem. 52, 711-760 (1983)

9. Mézes M, Virág Gy, Barta M, Abouzeid AD: Effect of lipid peroxide loading on lipid peroxidation and on the glutathione and cytochrome systems in rabbits. Acta Vet. Hung. 44, 443-450 (1996)

10. Mézes M, Virág Gy, Barta M, Erdélyi M: Effect of nutritional and genetic factors on glutathione peroxidase in rabbit. Curr. Top. Biophys. 22, 154-157 (1998)

11. Monks TJ, Lau SS: Activation and detoxification of bromobenzene in extrahepatic tissues. Life Sci. 35, 561-568 (1984)

12. Placer ZA, Cusham LL, Johnson BC: Estimation of product of lipid peroxidation (malonyl dialdehyde) in biochemical systems. Anal. Biochem. 16, 359-364 (1966)

13. Sedlak J, Lindsay RHC: Estimation of total, protein bound and non-protein sulfhydryl groups in tissue with Ellmann's reagent. Anal. Biochem. 25, 192-205 (1968)

14. Suchocka Z, Kobylinska K, Pachecka J: Activity of glutathione-dependent enzymes in long term diabetes. I. Activity of glutathione-S-transferase and glutathione peroxidase in the liver of alloxan induced diabetic rats. Acta Pol. Pharm. 52, 207-211 (1995)

15. Toronsco P, Smok G, Videla LA: Potentation of ischemia-reperfusion liver injury by hyperthyroidism in rat. Free Radic. Bio. Med. 23, 19-25 (1997)

16. Weichselbaum TE: An accurate and rapid method for the determination of protein in small amounts of serum and plasma. Am. J. Clin. Pathol. 16, 40-43 (1946)

17. Whanger P, Vendeland S, Park YC, Xia Y: Metabolism of subtoxic levels of selenium in animals and humans. Ann. Clin. Lab. Sci. 26, 88-113 (1996)

18. Zamorski R, Borowska K, Kopper J (1995): Selenium, zinc and magnesium content and glutathione peroxidase activity in blood of humans and some animal species. In: Proc. Mengen- und Spurenelementen 15. Arbeitstagung, Friedrich Schiller Universitat, Jena, pp. 421-427. 